\title{
SYNTHESIS AND SPECTROSCOPIC CHARACTERIZATION OF POLYNUCLEAR SILVER(I) COMPLEX WITH 2,2'-BIQUINOLINE
}

\author{
DEJAN M. GUREŠIĆ ${ }^{*}$, SONJA Ž. ĐURIĆ ${ }^{*}$, TINA P. ANDREJEVIĆ ${ }^{2}$ MIRJANA M. \\ POPSAVIN $^{3}$, BILJANA Đ. GLIŠIĆ ${ }^{2}$
}

${ }^{1}$ Faculty of Technical Sciences, University of Priština, Kosovska Mitrovica, Serbia

${ }^{2}$ Department of Chemistry, Faculty of Science, University of Kragujevac, Kragujevac, Serbia

${ }^{3}$ Department of Chemistry, Biochemistry and Environmental Protection, Faculty of Sciences, University of Novi Sad,

Novi Sad, Serbia

\begin{abstract}
Polynuclear silver(I) complex, $\left[\mathrm{Ag}\left(\mathrm{NO}_{3}-\mathrm{O}\right)\left(2,2^{\prime}-\mathrm{bq}-\mathrm{N}, N^{\prime}\right)\right]_{\mathrm{n}}$, was synthesized by the reaction of equimolar amount of silver(I) nitrate and $2,2^{\prime}$-biquinoline $\left(2,2^{\prime}-\mathrm{bq}\right)$ in ethanol at room temperature. The characterization of the complex was established on the basis of elemental microanalysis, IR, NMR $\left({ }^{1} \mathrm{H}\right.$ and ${ }^{13} \mathrm{C}$ ) and $\mathrm{UV}$-Vis spectroscopic techniques. The results of spectroscopic analyses revealed that in $\left[\mathrm{Ag}\left(\mathrm{NO}_{3}-O\right)\left(2,2^{\prime}-\mathrm{bq}-N, N^{\prime}\right)\right]_{\mathrm{n}}$ complex, $2,2^{\prime}-\mathrm{bq}$ ligand behaves as a chelate, while the remaining coordination sites are occupied by the oxygen atoms of two nitrates.
\end{abstract}

Keywords: Silver(I) complexes, $N$-Heterocycles, Polynuclear complexes, Spectroscopy.

\section{INTRODUCTION}

Silver(I) complexes with aromatic nitrogen-containing heterocycles ( $N$-heterocycles) have attracted a considerable attention in the field of pharmaceutical and supramolecular chemistry (Khlobystov et al., 2001; Medici et al., 2019). Thus, various silver(I) complexes with this type of ligands are known to exhibit remarkable antimicrobial activity against different Gram-positive and Gram-negative bacteria and fungal species, which are causative agents of many microbial infections (Nomiya et al., 2000; Rowan et al., 2006; Kalinowska-Lis et al., 2014; Kalinowska-Lis et al., 2015; Pettinari et al., 2011; Savić et al., 2016; Glišić et al., 2016; Savić et al., 2018; Andrejević et al., 2018; Pavić et al., 2019). Furthermore, silver(I) complexes with aromatic $N$-heterocycles have shown significant antiproliferative activity against different human tumor cell lines, being, in some cases, superior to the clinically used platinum(II) complexes (Banti et al., 2013).

The second important reason for investigation of silver(I) chemistry with aromatic $N$-heterocycles stems from the findings that the $\operatorname{Ag}(\mathrm{I})$ ion coordinated by these ligands is a favorable building block for coordination polymers, having potential applications for design of innovative materials, including liquid crystals (Khlobystov et al., 2001; Yeşilel et al., 2010; Pucci et al., 2011). In coordination polymers, $\operatorname{Ag}(\mathrm{I})$ ion can have coordination numbers between two and six, adopting various geometries, such as linear, bent, trigonal, T-shaped, tetrahedral, trigonal pyramidal and octahedral. Moreover, weak contacts, such as argentophilic $\mathrm{Ag}{ }^{\prime} \mathrm{Ag}, \mathrm{Ag}{ }^{\prime} \pi$ and $\mathrm{Ag}$ "solvent/counterion interactions, have significant influence on the structural

*Corresponding author: dejan.guresic@ @r.ac.rs CHEMISTRY properties of silver(I) coordination polymers in the solid state (Khlobystov et al., 2001; Fik et al., 2014).

In the design of silver(I) coordination polymers, various bridging and chelating aromatic $N$-heterocycles have been used. Among them, 2,2'-bipyridine (2,2'-bipy) and its derivatives have been a subject of research due to their coordination versatility which allowed the tuning of the topology, the supramolecular architectures and other features in a series of silver(I) complexes (Pucci et al., 2011; Bellusci et al., 2008; Bowmaker et al., 2005). Herein, 2,2'-biquinoline (2,2'-bq), which is a larger and more rigid $\pi$ system than 2,2'-bipy, was used as a ligand for complexation to $\operatorname{Ag}(\mathrm{I})$ ion. This ligand has two nitrogen-donors and the two flexible quinoline moiety linked together by a single $\mathrm{C}-\mathrm{C}$ bond, which allow its different coordination behaviour towards metal ions (Pucci et al., 2011). Considering this, the reaction of silver(I) nitrate with an equimolar amount of 2,2' biquinoline (2,2'-bq) was performed and polynuclear silver(I) complex, $\quad\left[\mathrm{Ag}\left(\mathrm{NO}_{3}-O\right)\left(2,2^{\prime}-\mathrm{bq}-N, N^{\prime}\right)\right]_{\mathrm{n}}$, was isolated and characterized by spectroscopy (IR, ${ }^{1} \mathrm{H}$ and ${ }^{13} \mathrm{C}$ NMR and UVVis).

\section{EXPERIMENTAL}

Reagents

Silver(I) nitrate, 2,2'-biquinoline (2,2'-bq), ethanol, dimethylformamide (DMF) and deuterated dimethylformamide $\left(\right.$ DMF- $\left.d_{7}\right)$ were purchased from the Sigma-Aldrich Chemical Co. All the employed chemicals were of analytical reagent grade and used without further purification.

\section{Measurements}

Elemental microanalysis of the silver(I) complex for carbon, hydrogen and nitrogen was performed by the 
Microanalytical Laboratory, Faculty of Chemistry, University of Belgrade. All NMR spectra were recorded at $25{ }^{\circ} \mathrm{C}$ on a Bruker Avance III $400 \mathrm{MHz}$ spectrometer $\left({ }^{1} \mathrm{H}\right.$ at $400 \mathrm{MHz},{ }^{13} \mathrm{C}$ at 101 $\mathrm{MHz}$. $5 \mathrm{mg}$ of 2,2'-bq and its silver(I) complex was dissolved in $0.6 \mathrm{~mL}$ of DMF- $d_{7}$ and transferred into a $5 \mathrm{~mm}$ NMR tube. Chemical shifts are expressed in $\mathrm{ppm}(\delta / \mathrm{ppm})$ and scalar couplings are reported in Hertz $(J / \mathrm{Hz})$. Chemical shifts were calibrated relative to those of the solvent. The IR spectra were recorded as $\mathrm{KBr}$ pellets on a Perkin-Elmer Spectrum One FT-IR spectrometer over the wavenumber range $4000-450 \mathrm{~cm}^{-1}$. The $\mathrm{UV}-\mathrm{V}$ is spectra were recorded over the wavelenth range of $900-$ $200 \mathrm{~nm}$ on a Shimadzu UV-1800 spectrophotometer after dissolving 2,2'-bq and its silver(I) complex in DMF. The concentration was $1.9 \cdot 10^{-5} \mathrm{M}$.

\section{Synthesis of $\left[\mathrm{Ag}\left(\mathrm{NO}_{3}-\mathrm{O}\right)\left(2,2^{\prime}-b q-N, N^{\prime}\right)\right]_{n}$ complex}

$5.0 \mathrm{~mL}$ of ethanolic solution of $\mathrm{AgNO}_{3}(1.0 \mathrm{mmol}, 169.9$ $\mathrm{mg}$ ) was added dropwise to ethanolic solution $(5.0 \mathrm{~mL})$ of 2,2 'bq $(1.0 \mathrm{mmol}, 256.3 \mathrm{mg})$ with stirring at room temperature. The stirring was continued for $3 \mathrm{~h}$ in the dark at room temperature, and after that time, the final solution was left to slowly evaporate. After a while, the pale-yellow crystals of silver(I) complex were obtained. These crystals were filtered off and dried in the dark at room temperature. The yield was $73 \%(311.1$ $\mathrm{mg})$.

$\left[\mathrm{Ag}\left(\mathrm{NO}_{3}-\mathrm{O}\right)\left(2,2^{\prime}-b q-N, N^{\prime}\right)\right]_{n}$. Anal. Calcd. for $\mathrm{C}_{18} \mathrm{H}_{12} \mathrm{AgN}_{3} \mathrm{O}_{3}$ (MW 426.18): C, 50.73; H, 2.84; N, 9.86\%. Found: C, 50.92; H, 2.89; N, 9.74\%. ${ }^{1} \mathrm{H}$ NMR (400 MHz, DMF$\left.d_{7}\right): \delta=7.56-7.66\left(m, 4 \mathrm{H}, \mathrm{H}-6\right.$ and H-7), $8.09\left(d d, 2 \mathrm{H}, J_{5,6}=\right.$ $\left.7.7 \mathrm{~Hz}, J_{5,7}=1.6 \mathrm{~Hz}, \mathrm{H}-5\right), 8.16\left(d d, 2 \mathrm{H}, J_{7,8}=8.3 \mathrm{~Hz}, J_{6,8}=1.1\right.$ $\mathrm{Hz}, \mathrm{H}-8), 8.83\left(d, 2 \mathrm{H}, J_{3,4}=8.7 \mathrm{~Hz}, \mathrm{H}-4\right), 8.89\left(d, 2 \mathrm{H}, J_{3,4}=\right.$ $8.7 \mathrm{~Hz}, \mathrm{H}-3) .{ }^{13} \mathrm{C}$ NMR (101 MHz, DMF- $\left.d_{7}\right): \delta=121.75(\mathrm{C}-3)$, 129.29 (C-5), 129.60 (C-6), 130.36 (C-4a), 130.93 (C-8), 132.70 (C-7), 141.06 (C-4), 147.43 (C-8a), 153.40 (C-2). IR (KBr, $\left.\mathrm{cm}^{-1}\right): \quad 3000 w \quad\left(v\left(\mathrm{C}_{\mathrm{ar}}-\mathrm{H}\right)\right), 1594 m, 1505 m \quad\left(v\left(\mathrm{C}_{\mathrm{ar}}=\mathrm{C}_{\mathrm{ar}}\right)\right.$ and $\left.v\left(\mathrm{C}_{\mathrm{ar}}=\mathrm{N}\right)\right), 1384 v s, 1302 s\left(v_{\mathrm{as}}\left(\mathrm{NO}_{3}\right)\right), 1326(v(\mathrm{C}-\mathrm{N})), 812 m$, $745 m(\gamma(\mathrm{Car}-\mathrm{H}))$. UV-Vis (DMF, $\left.\lambda_{\max }, \mathrm{nm}\right): 315.0\left(\varepsilon=2.5 \cdot 10^{4}\right.$ $\left.\mathrm{M}^{-1} \mathrm{~cm}^{-1}\right), 326.0 \quad\left(\varepsilon=2.9 \cdot 10^{4} \mathrm{M}^{-1} \mathrm{~cm}^{-1}\right), 339.0 \quad\left(\varepsilon=2.5 \cdot 10^{4}\right.$ $\left.\mathrm{M}^{-1} \mathrm{~cm}^{-1}\right), 355.0\left(\varepsilon=3.8 \cdot 10^{3} \mathrm{M}^{-1} \mathrm{~cm}^{-1}\right)$.

$2,2^{\prime}-b q$ (data given for comparative purposes). $\mathrm{MW}=$ 256.30. ${ }^{1} \mathrm{H}$ NMR $\left(400 \mathrm{MHz}, \mathrm{DMF}-d_{7}\right): \delta=7.54\left(d d d, 2 \mathrm{H}, J_{5,6}=\right.$ $\left.8.1 \mathrm{~Hz}, J_{6,7}=6.9 \mathrm{~Hz}, J_{6,8}=1.2 \mathrm{~Hz}, \mathrm{H}-6\right), 7.72\left(d d d, 2 \mathrm{H}, J_{7,8}=\right.$ $\left.8.4 \mathrm{~Hz}, J_{6,7}=6.9 \mathrm{~Hz}, J_{5,7}=1.4 \mathrm{~Hz}, \mathrm{H}-7\right), 7.94\left(d d, 2 \mathrm{H}, J_{5,6}=8.1\right.$ $\left.\mathrm{Hz}, J_{5,7}=1.1 \mathrm{~Hz}, \mathrm{H}-5\right), 8.07\left(b d, 2 \mathrm{H}, J_{7,8}=8.4 \mathrm{~Hz}, \mathrm{H}-8\right), 8.46$ $\left(d, 2 \mathrm{H}, J_{3,4}=8.6 \mathrm{~Hz}, \mathrm{H}-4\right), 8.73\left(d, 2 \mathrm{H}, J_{3,4}=8.6 \mathrm{~Hz}, \mathrm{H}-3\right) .{ }^{13} \mathrm{C}$ NMR (101 MHz, DMF- $\left.d_{7}\right): \delta=119.83(\mathrm{C}-3), 128.29$ (C-6), 128.99 (C-5), 129.53 (C-4a), 130.55 (C-8), 130.98 (C-7), 138.12 (C-4), 148.69 (C-8a), $156.72(\mathrm{C}-2)$. IR $\left(\mathrm{KBr}, \mathrm{cm}^{-1}\right): \sim 3000 w$ $\left(v\left(\mathrm{C}_{\mathrm{ar}}-\mathrm{H}\right)\right), 1594 \mathrm{~s}, 1497 m\left(v\left(\mathrm{C}_{\mathrm{ar}}=\mathrm{C}_{\mathrm{ar}}\right)\right.$ and $\left.v\left(\mathrm{C}_{\mathrm{ar}}=\mathrm{N}\right)\right), 1327(v(\mathrm{C}-$ $\mathrm{N})), 829 v s, 738 v s(\gamma(\mathrm{Car}-\mathrm{H}))$. UV-Vis (DMF, $\left.\lambda_{\max }, \mathrm{nm}\right): 315.0(\varepsilon$ $\left.=3.6 \cdot 10^{4} \mathrm{M}^{-1} \mathrm{~cm}^{-1}\right), 326.0\left(\varepsilon=4.2 \cdot 10^{4} \mathrm{M}^{-1} \mathrm{~cm}^{-1}\right), 339.0\left(\varepsilon=3.3 \cdot 10^{4}\right.$ $\left.\mathrm{M}^{-1} \mathrm{~cm}^{-1}\right)$.

\section{RESULTS AND DISCUSSION}

Synthesis and structural features of $\left[\mathrm{Ag}\left(\mathrm{NO}_{3}-\mathrm{O}\right)\left(2,2^{\prime}-b q-N, N^{\prime}\right)\right]_{n}$ complex

Silver(I) complex with 2,2'-biquinoline (2,2'-bq) was synthesized according to the route presented in Figure 1 . The reaction of $\mathrm{AgNO}_{3}$ and 2,2'-bq in $1: 1$ mole ratio in ethanol at room temperature yielded polynuclear $\left[\mathrm{Ag}\left(\mathrm{NO}_{3}-O\right)\left(2,2^{\prime}-\mathrm{bq}-\right.\right.$ $\left.\left.N, N^{\prime}\right)\right]_{\mathrm{n}}$ complex. The composition and structural formula of this silver(I) complex was consistent with elemental analysis, IR, solution NMR $\left({ }^{1} \mathrm{H}\right.$ and $\left.{ }^{13} \mathrm{C}\right)$ and UV-Vis spectroscopic results. We isolated the crystals of the complex suitable for X-ray analysis, however, the crystallographic results indicated that the crystal structure of $\left[\mathrm{Ag}\left(\mathrm{NO}_{3}-O\right)\left(2,2^{\prime}-\mathrm{bq}-N, N^{\prime}\right)\right]_{\mathrm{n}}$ was very similar to that for the complex obtained in the reaction of $\mathrm{AgNO}_{3}$ and 2,2'-bq in acetonitrile (Bowmaker et al., 2005). Considering this, the crystal structure of polynuclear $\left[\mathrm{Ag}\left(\mathrm{NO}_{3}-O\right)\left(2,2^{\prime}-\mathrm{bq}-N, N^{\prime}\right)\right]_{\mathrm{n}}$ complex will not be discussed herein.

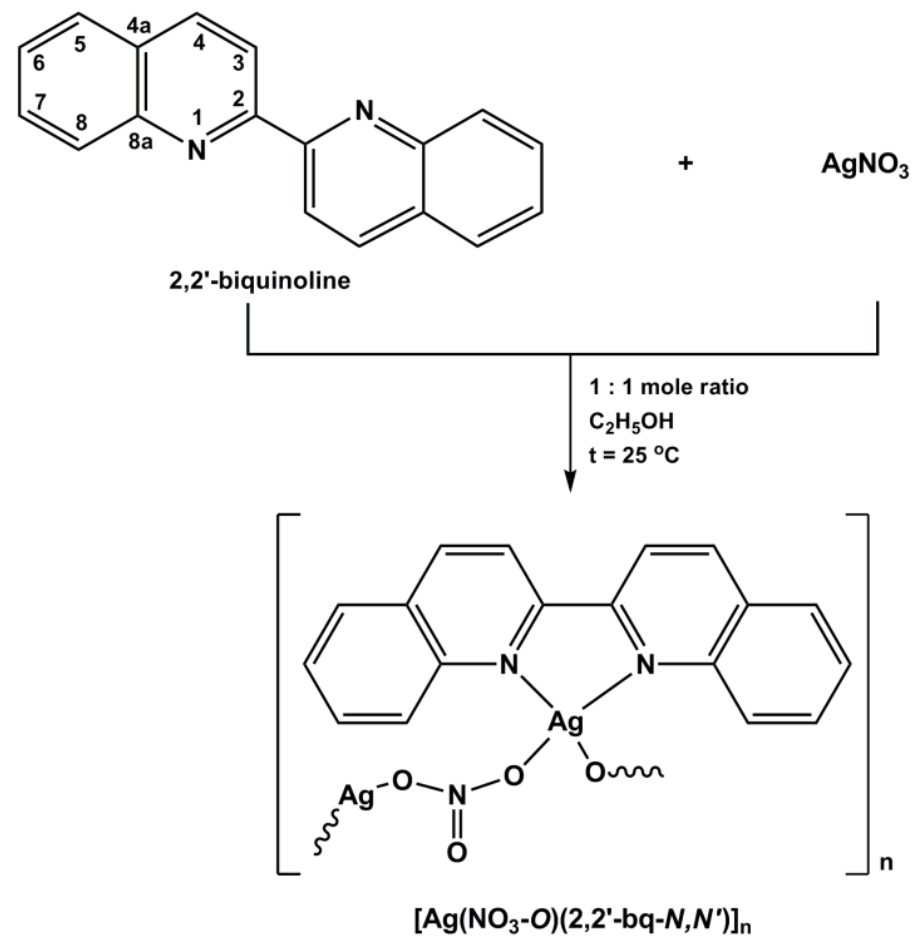

Figure 1. Schematic presentation of the synthesis of $\left[\mathrm{Ag}\left(\mathrm{NO}_{3}\right.\right.$ $O)\left(2,2^{\prime}\right.$-bq- $\left.\left.N, N^{\prime}\right)\right]_{\mathrm{n}}$ complex. Numbering scheme of carbon and nitrogen atoms in $2,2^{\prime}$-bq is in agreement with IUPAC recommendations for fused ring systems.

\section{Spectroscopic characterization}

The IR, NMR $\left({ }^{1} \mathrm{H}\right.$ and $\left.{ }^{13} \mathrm{C}\right)$, and UV-Vis spectroscopic data for 2,2'-bq and $\left[\mathrm{Ag}\left(\mathrm{NO}_{3}-O\right)\left(2,2^{\prime}-\mathrm{bq}-N, N^{\prime}\right)\right]_{\mathrm{n}}$ complex are listed in the Experimental section. In the IR spectrum of $\left[\mathrm{Ag}\left(\mathrm{NO}_{3}-\right.\right.$ $O)\left(2,2^{\prime}\right.$ 'bq- $\left.\left.N, N^{\prime}\right)\right]_{\mathrm{n}}$ complex, two strong bands at 1384 and 1302 $\mathrm{cm}^{-1}$ due to the nitrate asymmetric stretching vibrations are observed (Table 1), indicating that nitrate is coordinated to $\operatorname{Ag}(\mathrm{I})$ ion (Potapov et al., 2015). The splitting of the nitrate asymmetric 
stretching vibrations in the IR spectrum of $\left[\mathrm{Ag}\left(\mathrm{NO}_{3}-O\right)\left(2,2^{\prime}\right.\right.$ '-bq$\left.\left.N, N^{\prime}\right)\right]_{\mathrm{n}}$ is in accordance with that observed in the spectra of polynuclear $\left[\mathrm{Ag}\left(\mathrm{NO}_{3}-\mathrm{O}\right)(\mathrm{qz})\right]_{\mathrm{n}}$ (qz is quinazoline) (Savić et al., 2016) and $\left[\mathrm{Ag}\left(\mathrm{NO}_{3}-\mathrm{O}\right)(\mathrm{L}-\mathrm{N} 4)_{2}\right]_{\mathrm{n}}$ complexes, $\mathrm{L}$ is 1-benzyl- $1 \mathrm{H}$ tetrazole (bntz), 1-benzyl-1H-tetrazol-5-amine (bntza) and 1-(4methoxybenzyl)-1H-tetrazol-5-amine (mbntza) (Andrejević et al., 2018), all containing nitrate as a bridging ligand between two $\mathrm{Ag}(\mathrm{I})$ ions (Table 1$)$.

Table 1. IR asymmetric nitrate stretching frequencies $\left(v, \mathrm{~cm}^{-1}\right)$ of polynuclear silver(I) complexes containing nitrate as a bridging ligand

\begin{tabular}{|c|c|c|}
\hline Silver(I) complex & $v_{\text {asym }}\left(\mathrm{NO}_{3}{ }^{-}\right)$ & Ref. \\
\hline$\left[\mathrm{Ag}\left(\mathrm{NO}_{3}-\mathrm{O}\right)\left(2,2^{\prime}-\mathrm{bq}-N, N^{\prime}\right)\right]_{\mathrm{n}}$ & 1384,1302 & This work \\
\hline$\left[\mathrm{Ag}\left(\mathrm{NO}_{3}-\mathrm{O}\right)(\mathrm{qz})\right]_{\mathrm{n}}$ & 1377,1352 & $\begin{array}{c}\text { Savić et al., } \\
2016 .\end{array}$ \\
\hline$\left[\mathrm{Ag}\left(\mathrm{NO}_{3}-\mathrm{O}\right)(\text { bntz-N4})_{2}\right]_{\mathrm{n}}$ & 1384,1354 & $\begin{array}{c}\text { Andrejević } \\
\text { et al., 2018. }\end{array}$ \\
\hline$\left[\mathrm{Ag}\left(\mathrm{NO}_{3}-\mathrm{O}\right)(\text { bntza- } N 4)_{2}\right]_{\mathrm{n}}$ & 1384,1364 & $\begin{array}{c}\text { Andrejević } \\
\text { et al., 2018. }\end{array}$ \\
\hline$\left[\mathrm{Ag}\left(\mathrm{NO}_{3}-\mathrm{O}\right)(\text { mbntza- } N 4)_{2}\right]_{\mathrm{n}}$ & 1384,1306 & $\begin{array}{c}\text { Andrejević } \\
\text { et al., 2018. }\end{array}$ \\
\hline
\end{tabular}

Solution state ${ }^{1} \mathrm{H}$ and ${ }^{13} \mathrm{C}$ NMR spectra were measured in deuterated DMF in order to confirm the bidentate coordination of 2,2'-bq to the $\operatorname{Ag}(\mathrm{I})$ ion. The spectra of the $\left[\mathrm{Ag}\left(\mathrm{NO}_{3}-O\right)\left(2,2^{\prime}\right.\right.$ '-bq$\left.\left.N, N^{\prime}\right)\right]_{\text {n }}$ complex were compared with those for the corresponding ligand. Numbering scheme of carbon atoms in 2,2'-bq is presented in Figure 1. In the ${ }^{1} \mathrm{H}$ NMR spectrum of the silver(I) complex, there are noticeable downfield shifts $(+0.16$ and +0.37 ppm) for the H-3 and H-4 protons of the pyridyl moiety of 2,2'$\mathrm{bq}$ in respect to those for these protons of the free ligand (Figure 2 ). The shifting of the resonance due to the H-3 proton is thought to be a consequence of a change of 2,2'-bq configuration upon its coordination from preferred transoid form to a cisoid one (Starosta et al., 2013). Furthermore, the resonances of the H-5 H-8 protons are slightly shifted compared to those of the uncoordinated 2,2'-bq. The small coordination shifts observed for these protons in $\left[\mathrm{Ag}\left(\mathrm{NO}_{3}-O\right)\left(2,2^{\prime}-\mathrm{bq}-N, N^{\prime}\right)\right]_{\mathrm{n}}$ complex are in agreement with the spectroscopic features of silver(I) complexes with aromatic nitrogen-containing heterocyclic ligands, due to the fast ligand exchange phenomenon on the NMR timescale (Kalinowska-Lis et al., 2015). For the presently investigated silver(I) complex, the order of ${ }^{1} \mathrm{H}$ resonances is in accordance with those for the mononuclear [Ag(tsac-S)(2,2'-bq$\left.\left.N, N^{\prime}\right)\right] \cdot \mathrm{CH}_{3} \mathrm{CN}$ complex, which spectrum is recorded in DMSO$d_{6}$ (tsac is thiosaccharinate anion) (Burrow et al., 2016). The latter complex was previously obtained in the reaction of hexameric $\left[\mathrm{Ag}_{6}(\mathrm{tsac})_{6}\right]$ complex with $2,2^{\prime}$-bq in acetonitrile as solvent (Burrow et al., 2016).

The ${ }^{13} \mathrm{C}$ NMR spectrum of $\left[\mathrm{Ag}\left(\mathrm{NO}_{3}-O\right)\left(2,2^{\prime}-\mathrm{bq}-N, N^{\prime}\right)\right]_{\mathrm{n}}$ in DMF $-d_{7}$ displays nine signals differently positioned from those of the uncoordinated ligand. Within the 2,2'-biquinoline, the nitrogen-adjacent $\mathrm{C}$-atoms, i.e. $\mathrm{C}-2$ and $\mathrm{C}-8 \mathrm{a}$ are shielded (-3.32 ppm for $\mathrm{C} 2$ and -1.26 ppm for $\mathrm{C} 8 \mathrm{a}$ ), while the more far-distant ring carbons are deshielded (up to $+2.94 \mathrm{ppm}$ for $\mathrm{C} 4$ ).

\section{B}
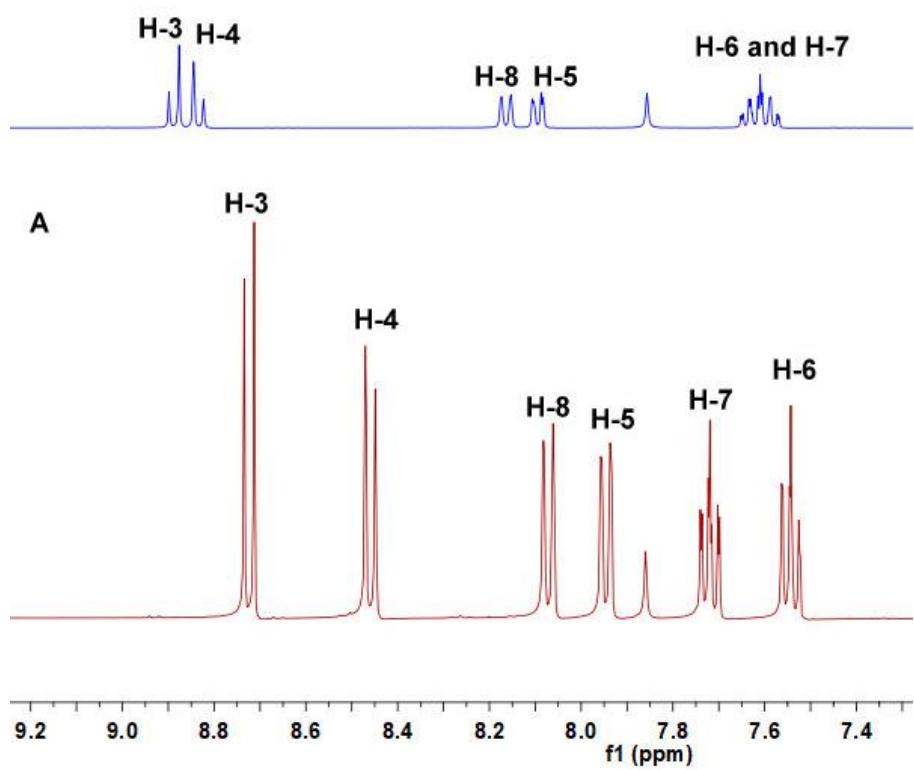

Figure 2. ${ }^{1} \mathrm{H}$ NMR spectra of 2,2 ' $-\mathrm{bq}(\mathbf{A})$ and $\left[\mathrm{Ag}\left(\mathrm{NO}_{3}-\mathrm{O}\right)\left(2,2^{\prime}-\right.\right.$ bq- $\left.\left.N, N^{\prime}\right)\right]_{\mathrm{n}}$ complex $(\mathbf{B})$ measured in $\mathrm{DMF}-d_{7}(400 \mathrm{MHz})$.

The UV-Vis spectrum of $\left[\mathrm{Ag}\left(\mathrm{NO}_{3}-O\right)\left(2,2^{\prime}-\mathrm{bq}-N, N^{\prime}\right)\right]_{\mathrm{n}}$ complex recorded in DMF at room temperature shows three bands with absorption maxima at $\lambda=315.0,326.0$ and $339.0 \mathrm{~nm}$ and lower intensity shoulder at $\lambda=355.0 \mathrm{~nm}$ (Figure 3 ).

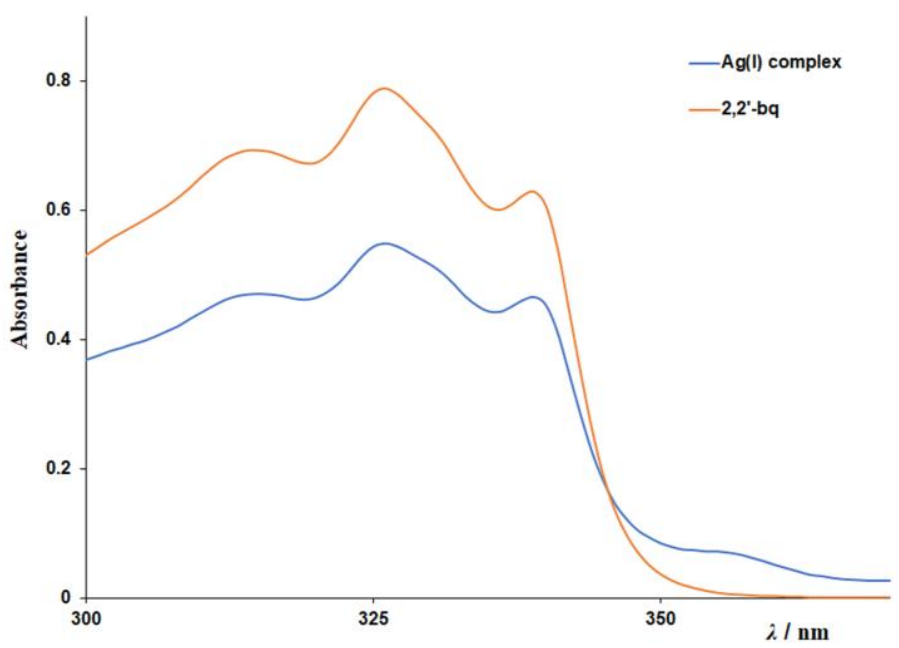

Figure 3. UV-Vis spectra of $2,2^{\prime}$ '-bq and $\left[\mathrm{Ag}\left(\mathrm{NO}_{3}-\mathrm{O}\right)\left(2,2^{\prime}\right.\right.$ '-bq$\left.\left.N, N^{\prime}\right)\right]_{\mathrm{n}}$ complex measured in DMF $\left(\mathrm{c}=1.9 \cdot 10^{-5} \mathrm{M}\right)$.

As can be seen, the spectral features of this complex are similar with those of the 2,2'-bq, differing only in the appearance of a shoulder in the spectrum of the complex. Considering this 
and the fact that the $d^{10}$ metal coordination does not influence the electronic transitions already active in the ligand, the three bands at $\lambda=315.0,326.0$ and $339.0 \mathrm{~nm}$ can be attributed to the $\pi \rightarrow \pi^{*}$ transitions of the aromatic rings of the 2,2'-bq and originate from an intraligand charge transfer (ILCT) (Pucci et al., 2011). On the other hand, the appearance of a shoulder at $\lambda=355.0 \mathrm{~nm}$ in the spectrum of the complex is attributed to the complexation process and can be assigned to the charge transfer processes between silver(I) ion and 2,2'-bq ligand (Tailor et al., 2015; Rusu et al., 2016; Kharat et al., 2011). No $d \rightarrow d$ transitions are expected for a complex of $d^{10}$ metal ion.

\section{CONCLUSION}

We have shown that the reaction between $\mathrm{AgNO}_{3}$ and 2,2'biquinoline $\left(2,2^{\prime}-\mathrm{bq}\right)$ in $1: 1$ mole ratio in ethanol leads to the formation of polynuclear silver(I) complex, $\left[\mathrm{Ag}\left(\mathrm{NO}_{3}-\mathrm{O}\right)\left(2,2^{\prime}-\right.\right.$ bq- $\left.\left.N, N^{\prime}\right)\right]_{\mathrm{n}}$. In this complex, $\operatorname{Ag}(\mathrm{I})$ ion is bidentately coordinated by 2,2 '-biquinoline and by the oxygen atoms of two nitrate ions. The present results are in contrast to those previously reported for the silver(I) complexes obtained in the reactions of $\mathrm{AgClO}_{4}$, $\mathrm{AgCF}_{3} \mathrm{SO}_{3}$ and $\left.\left[\mathrm{Ag}_{6} \text { (tsac) }\right)_{6}\right]$ with 2,2'-biquinoline, all leading to the formation of discrete mononuclear $\left[\mathrm{Ag}\left(\mathrm{ClO}_{4}-\mathrm{O}, \mathrm{O}^{\prime}\right)\left(2,2^{\prime}-\mathrm{bq}-\right.\right.$ $\left.\left.N, N^{\prime}\right)\right], \quad\left[\mathrm{Ag}\left(\mathrm{CF}_{3} \mathrm{SO}_{3}-\mathrm{O}\right)\left(2,2^{\prime}-\mathrm{bq}-N, N^{\prime}\right)\left(\mathrm{H}_{2} \mathrm{O}\right)\right]$ and $\quad[\mathrm{Ag}($ tsac$S)\left(2,2^{\prime}\right.$-bq- $\left.\left.N, N^{\prime}\right)\right] \cdot \mathrm{CH}_{3} \mathrm{CN}$ species, respectively (Bowmaker et al., 2005; Pucci et al., 2011; Burrow et al., 2016). This study confirms that the constitution of the silver(I) complexes with aromatic $N$-heterocyclic ligands strongly depends on the reaction conditions, such as starting silver(I) compound and solvent. All these together should be carefully considered during preparation of new silver(I) complexes for different applications in medicinal and supramolecular chemistry.

\section{ACKNOWLEGMENTS}

This research has been financially supported by the Ministry of Education, Science and Technological Development of the Republic of Serbia (Agreement No. 451-03-68/202014/200042). The authors wish to thank Dr. Hubert Wadepohl (Institute of Inorganic Chemistry, Heidelberg University) for performing single-crystal X-ray diffraction analysis.

\section{REFERENCES}

Andrejević, T. P., Nikolić, A. M., Glišić, B. Đ., Wadepohl, H., Vojnovic, S., Zlatović, M., Petković, M., Nikodinovic-Runic, J., Opsenica, I. M., \& Djuran, M. I. 2018. Synthesis, structural characterization and antimicrobial activity of silver(I) complexes with 1-benzyl-1H-tetrazoles. Polyhedron, 154, pp. 325-333. doi.10.1016/j.poly.2018.08.001

Banti, C. N., \& Hadjikakou S. K. 2013. Anti-proliferative and anti-tumor activity of silver(I) compounds. Metallomics, 5, pp. 569-596. doi.10.1039/C3MT00046J
Bellusci, A., Crispini, A., Pucci, D., Szerb, E. I., \& Ghedini, M. 2008. Structural variations in bipyridine silver(I) complexes: Role of the substituents and counterions. Crystal Growth and Design, 8, pp. 3114-3122. doi.10.1021/cg8003323

Bowmaker, G. A., Effendy, Marfuah, S., Skelton, B. W., \& White, A. H. 2005. Syntheses, structures and vibrational spectroscopy of some $1: 1$ and $1: 2$ adducts of silver(I) oxyanion salts with 2,2'-bis(pyridine) chelates. Inorganica Chimica Acta, 358, pp. 4371-4388. doi.10.1016/j.ica.2005.04.001

Burrow, R. A., Belmonte, G. Z., Dorn, V., \& Dennehy, M. 2016. Three new $\operatorname{Ag}(\mathrm{I})$ thiosaccharinate complexes: Synthesis, structural studies, spectral characterization and theoretical analysis. Inorganica Chimica Acta, 450, pp. 39-49. doi.10.1016/j.ica.2016.05.004

Fik, M. A., Gorczyński, A., Kubicki, M., Hnatejko, Z., FedorukWyszomirska, A., Wyszko, E., Giel-Pietraszuk, M., \& Patroniak, V. 2014. 6,6"-Dimethyl-2,2':6',2"-terpyridine revisited: New fluorescent silver(I) helicates with in vitro antiproliferative activity via selective nucleoli targeting. European Journal of Medicinal Chemistry, 86, pp. 456-468. doi.10.1016/j.ejmech.2014.09.004

Glišić, B. Đ., Senerovic, L., Comba, P., Wadepohl, H., Veselinovic, A., Milivojevic, D. R., Djuran, M. I., \& Nikodinovic-Runic, J. 2016. Silver(I) complexes with phthalazine and quinazoline as effective agents against pathogenic Pseudomonas aeruginosa strains. Journal of Inorganic Biochemistry, 155, pp. 115-128. doi.10.1016/j.jinorgbio.2015.11.026

Kalinowska-Lis, U., Felczak, A., Chęcińska, L., Lisowska, K., \& Ochocki, J. 2014. Synthesis, characterization and antimicrobial activity of silver(I) complexes of hydroxymethyl derivatives of pyridine and benzimidazole. Journal of Organometallic Chemistry, 749, pp. 394-399. doi.10.1016/j.jorganchem.2013.10.035

Kalinowska-Lis, U., Felczak, A., Chęcińska, L., Zawadzka, K., Patyna, E., Lisowska, K., \& Ochocki, J. 2015. Synthesis, characterization and antimicrobial activity of water-soluble silver(I) complexes of metronidazole drug and selected counter-ions. Dalton Transactions, 44, pp. 8178-8189. doi.10.1039/C5DT00403A

Kharat, A. N., Bakhoda, A., Foroutannejad, S., \& Foroutannejad, C. 2011. Molecular structure and antimicrobial activity of a luminescent dinuclear silver(I) complex of phenyl- bis(2- pyridyl)phosphine. Zeitschrift für Anorganische und Allgemeine Chemie, 637, pp. 2260-2264. doi.10.1002/zaac.201100235

Khlobystov, A. N., Blake, A. J., Champness, N. R., Lemenovskii, D. A., Majouga, A. G., Zyk, N. V., \& Schröder, M. 2001. Supramolecular design of onedimensional coordination polymers based on silver(I) complexes of aromatic nitrogen-donor ligands. Coordination Chemistry Reviews, 222, pp. 155-192. doi.10.1016/S00108545(01)00370-8

Medici, S., Peana, M., Nurchi, V. M., \& Zoroddu, M. A. 2019. Medical uses of silver: History, myths, and scientific evidence. Journal of Medicinal Chemistry, 62, pp. $5923-$ 5943. doi.10.1021/acs.jmedchem.8b01439

Nomiya, K., Takahashi, S., Noguchi, R., Nemoto, S., Takayama, T., \& Oda, M. 2000. Synthesis and characterization of water- 
soluble silver(I) complexes with L-histidine $\left(\mathrm{H}_{2}\right.$ his $)$ and (S)(-)-2-pyrrolidone-5-carboxylic acid $\left(\mathrm{H}_{2}\right.$ pyrrld) showing a wide spectrum of effective antibacterial and antifungal activities. Crystal structures of chiral helical polymers $[\mathrm{Ag}(\text { Hhis })]_{\mathrm{n}}$ and $\left\{[\mathrm{Ag}(\mathrm{Hpyrrld})]_{2}\right\}_{\mathrm{n}}$ in the solid state. Inorganic Chemistry, 39, pp. 3301-3311. doi.10.1021/ic990526o

Pavić, A., Savić, N. D., Glišić, B. Đ., Crochet, A., Vojnovic, S., Kurutos, A., Stanković, D. M., Fromm, K. M., NikodinovicRunic, J., \& Djuran, M. I. 2019. Silver(I) complexes with 4,7-phenanthroline efficient in rescuing the zebrafish embryos of lethal Candida albicans infection. Journal of Inorganic Biochemistry, 195, pp. 149-163. doi.10.1016/j.jinorgbio.2019.03.017

Pettinari, C., Marchetti, F., Lupidi, G., Quassinti, L., Bramucci, M., Petrelli, D., Vitali, L. A., da Silva, M. F. C. G., Martins, L. M. D. R. S., Smoleński, P., \& Pombeiro, A. J. L. 2011. Synthesis, antimicrobial and antiproliferative activity of novel silver(I) tris(pyrazolyl)methanesulfonate and 1,3,5triaza-7-phosphadamantane complexes. Inorganic Chemistry, 50, pp. 11173-11183. doi.10.1021/ic201714c

Potapov, A. S., Nudnova, E. A., Khlebnikov, A. I., Ogorodnikov, V. D., \& Petrenko, T. V. 2015. Synthesis, crystal structure and electrocatalytic activity of discrete and polymeric copper(II) complexes with bitopic bis(pyrazol-1-yl)methane ligands. Inorganic Chemistry Communications, 53, pp. 72-75. doi.10.1016/j.inoche.2015.01.024

Pucci, D., Crispini, A., Ghedini, M., Szerb, E. I., \& La Deda, M. 2011. 2,2'-Biquinolines as test pilots for tuning the colour emission of luminescent mesomorphic silver(I) complexes. Dalton Transactions, 40, pp. 4614-4622. doi.10.1039/C0DT01842B

Rowan, R., Tallon, T., Sheahan, A. M., Curran, R., McCann, M., Kavanagh, K., Devereux, M., \& McKee, V. 2006. 'Silver bullets' in antimicrobial chemotherapy: Synthesis, characterisation and biological screening of some new $\mathrm{Ag}(\mathrm{I})$ containing imidazole complexes. Polyhedron, 25, pp. 17711778. doi.10.1016/j.poly.2005.11.021
Rusu, A., Hancu, G., Tóth, G., Vancea, S., Toma, F., Mare, A. D., Man, A., Niţulescu, G. M., \& Uivarosi, V. 2016. New silver complexes with levofloxacin: Synthesis, characterization and microbiological studies. Journal of Molecular Structure, 1123, pp. 384-393. doi.10.1016/j.molstruc.2016.07.035

Savić, N. D., Glišić, B. Đ., Wadepohl, H., Pavic, A., Senerovic, L., Nikodinovic-Runic, J., \& Djuran, M. I. 2016. Silver(I) complexes with quinazoline and phthalazine: Synthesis, structural characterization and evaluation of biological activities. MedChemComm, 7, pp. 282-291. doi.10.1039/C5MD00494B

Savić, N. D., Vojnovic, S., Glišić, B. Đ., Crochet, A., Pavic, A., Janjić, G. V., Pekmezović, M., Opsenica, I. M., Fromm, K. M., Nikodinovic-Runic, J., \& Djuran, M. I. 2018. Mononuclear silver(I) complexes with 1,7-phenanthroline as potent inhibitors of Candida growth. European Journal of Medicinal Chemistry, 156, pp. 760-773. doi.10.1016/j.ejmech.2018.07.049

Starosta, R., Brzuszkiewicz, A., Bykowska, A., Komarnicka, U. K., Bażanów, B., Florek, M., Gadzała, Ł., Jackulak, N., Król, J., \& Marycz, K. 2013. A novel copper(I) complex, [CuI(2,2'biquinoline $\left.) \mathrm{P}\left(\mathrm{CH}_{2} \mathrm{~N}\left(\mathrm{CH}_{2} \mathrm{CH}_{2}\right)_{2} \mathrm{O}\right)_{3}\right] \quad-\quad$ Synthesis, characterisation and comparative studies on biological activity. Polyhedron, 50, pp. 481-489. doi.10.1016/j.poly.2012.11.033

Tailor, S. M., \& Patel. U. H. 2015. Synthesis, spectroscopic characterization, antimicrobial activity and crystal structure of silver and copper complexes of sulfamethazine. Journal of Coordination Chemistry, 68, pp. 2192-2207. doi.10.1080/00958972.2015.1055258

Yeşilel, O. Z., Kaştaş, G., Darcan, C., İlker, İ., Paşaoğlu, H., \& Büyükgüngör, O. 2010. Syntheses, thermal analyses, crystal structures and antimicrobial properties of silver(I)saccharinate complexes with diverse diamine ligands. Inorganica Chimica Acta, 363, pp. 1849-1858. doi.10.1016/j.ica.2010.02.013 